\title{
Financial Distress Risk and Momentum Effects: Evidence from China's Stock Market
}

\author{
Qian Wang ${ }^{1}$ \\ ${ }^{1}$ School of Business Administration, Georgia Southwestern State University, Americus, Georgia, USA \\ Correspondence: Qian Wang, School of Business Administration, Georgia Southwestern State University, \\ Americus, Georgia, 31709, USA. Tel: 1-229-931-2123. E-mail: qian.wang@ gsw.edu
}

Received: October 2, 2017

Accepted: October 30, 2017

Online Published: November 15, 2017

doi:10.5539/ijef.v9n12p153

URL: https://doi.org/10.5539/ijef.v9n12p153

\begin{abstract}
I examine the relation of distress risk to size, book-to-market, and momentum effects in China's stock market. Consistent with the market underreaction hypothesis, I find that distressed firms underperform non-distressed firms in China's stock market and the momentum factor proxies for distress risk in our sample period. My study also shows that the explanatory power of the momentum effect is subsumed when the distress factor is present.
\end{abstract}

Keywords: financial distress risk, size effects, book-to-market effects, momentum effects, Altman's z"'-score

\section{Introduction}

Existing evidence on the relation of distress risk to size, book-to-market, and momentum effects is contradictory. The distress factor hypothesis states that if the size or book-to-market factors capture distress risk to explain the cross-sectional variation in stock returns, firms with a small size and/or a high market-to-book ratio are more likely to be associated with financial distress and that investors will charge a premium for bearing such risk (Chan, Chen, \& Hsieh, 1985; Fama \& French, 1996; Vassalou \& Xing, 2004). Consistent with this hypothesis, Chan et al. (1985), Fama and French (1993, 1995, 1996), and Vassalou and Xing (2004) find a positive association both between distress risk and size effects and between distress risk and book-to-market effects. In contrast, the study of Dichev (1998) and Griffin and Lemmon (2002) shows that most distressed firms have a lower book-to-market ratio. In addition, Dichev (1998) finds that the size effect among distressed firms disappears over specific time periods. Their evidence predicts a negative premium in stock returns for firms suffering from financial distress. Agarwal and Taffler (2008), Campbell, Hilscher, and Szilagyi (2008), and Ferguson and Shockley (2003) find that distressed firms earn lower stock returns than non-distressed firms, which confirms the existence of a negative premium for distressed firms. The market underreaction hypothesis appears to be a reasonable explanation for the negative premium. It posits that investors react slowly to the public information, thus leading to the information being slowly incorporated into stock prices, which causes the momentum effect. Jegadeesh and Titman (1993) introduces the momentum effect by finding that the recent past winners outperform recent past losers.

In this paper, I investigate the significance of the size, book-to-market, and momentum factors in capturing financial distress risk in China's stock market. As an emerging market, China's stock market has a short history and is immature. A large subset of Chinese investors consists of individual investors and exhibits strong speculative behavior. These individual investors usually hold stocks for a short term, tend to sell stock winners prematurely to lock in gains, and are reluctant to sell stock losers at a loss below the purchasing price. This behavior will make the market underreact to the public news and finally lead to momentum in stock returns (Grinblatt \& Han, 2005; Frazzini, 2006). Consistent to the market reaction hypothesis, I would expect that distressed firms underperform non-distressed firms and that the momentum factor can be explained by distress risk. As a result, the momentum effect will disappear when controlling for distress risk.

Our data are from the China Stock Market and Accounting Research (CSMAR) database. I draw the sample from all the A-shares (Note 1) listed on the Shanghai Stock Exchange and the Shenzhen Stock Exchange between January 1998 and September 2016. I use Altman's (1983) z"-score as a proxy for distress risk and divide the sample data into two groups: low z" firms (z"<1.1) and high z" firms (z">2.6). In comparison to high z" firms, low z" firms have higher financial leverage and make less profits, which are characteristics associated with distressed firms. Thus low z" firms represent Chinese distressed firms well and high z" firms can represent 
non-distressed firms. I use Carhart's (1997) four-factor model to investigate the relation of distress risk to size, book-to-market, and momentum effects in China's stock market. I find that the size and book-to-market effects cannot be explained by distress risk, inconsistent with the distress factor hypothesis. On the contrary, my findings are consistent with the market underreaction hypothesis. I find that in China's stock market, low z" firms underperform high z" firms and the momentum factor proxies for distress risk in our sample period. Furthermore, the explanatory power of the momentum effect is subsumed when the distress factor is present.

Our study is motivated by Agarwal and Taffler (2008). They find that market underreaction drives the momentum effects in the UK market, while my study provides rich evidence on the momentum effect in China's stock market. Since most literature has focused on developed markets, e.g. the US market, the UK market, and the Japanese market, our research extends the literature to emerging markets.

The remainder of the paper proceeds as follows. Section 2 describes the data and methodology. Section 3 presents empirical findings, and Section 4 concludes the paper.

\section{Data and Methodology}

I draw the sample from all the A-shares listed on the Shanghai Stock Exchange and the Shenzhen Stock Exchange for the period between January 1998 and September 2016. All the data are retrieved from the China Stock Market and Accounting Research (CSMAR) database. The corporate accounting data come from the CSMAR China Stock Market Financial Statements Database and the monthly stock returns, market returns, and risk free rates are obtained from the CSMAR China Stock Trading Database. The denominations of values are in Chinese Renminbin (RMB). To be included in the sample, data are cleared based on five filters as following: 1) firms from the financial sector are excluded from the sample; 2) firms with negative book values of equity are excluded from the sample; 3) firms have to be listed on the stock exchange for at least 36 months before the portfolio formation date; 4) all the variables are winsorized at the upper and the lower one percentiles to mitigate outlier effects; and 5) any observations with missing data for the variables are excluded from the sample.

I use Altman's (1983) z"-score as a proxy for distress risk. The z"-score model is a modified version of the z-score model (Altman, 1968) and developed by Altman (1983) for private manufacturing and non-manufacturing firms. The smaller the $\mathrm{z}$ "-score is, the more likely it is that companies will be in distress. Altman (1983) also demonstrate that firms with the z"-score less than 1.1 are more likely in a distress zone, while firms with the z"-score greater than 2.6 are likely to fall in a health zone. According to Altman's (1983) zones of discrimination, I divide the sample data into two groups: low z" firms $(z$ " $<1.1)$ and high $z$ " firms (z">2.6). The firms with the z"-score between 1.1 and 2.6 are excluded from the sample. Overall, the sample consists of 286,341 firm-month observations corresponding to 2,649 unique firms.

Altman, Iwanicz-Drozdowska, Laitinen, and Suvas (2016) use a very large international dataset, including 32 Chinese distressed firms, to assess the classification performance of the z"-score model in bankruptcy prediction and find that the original z"-score performs very well in China. Following Altman et al. (2016), the z"-score model is specified as

$$
Z "=3.25+6.56 \cdot X_{1}+3.26 \cdot X_{2}+6.72 \cdot X_{3}+1.05 \cdot X_{4}
$$

where

$\mathrm{X}_{1}=$ Working capital/Total assets

$\mathrm{X}_{2}=$ Retained Earnings/Total assets

$\mathrm{X}_{3}=$ Earnings before interest and taxes/Total assets

$\mathrm{X}_{4}=$ Book value of equity/Book value of total liabilities

Table 1 presents the difference in characteristics between firms with the $\mathrm{z}$ "-score less than 1.1 and firms with the z"-score greater than 2.6. I conduct paired $t$-tests with respect to the z"-score, leverage, ROA, and prior-year stock returns. Leverage is the ratio of the total liabilities to the book value of total assets. Companies' probability measure, ROA, is the ratio of the net income to the book value of total assets. Prior-Year Stock Returns are one-year buy-and-hold returns from January to December in the prior year. For example, the year 1998 corresponds to the period from January 1997 to December 1997. In total, there are 527 low z" firms (z"<1.1) and 24,712 high z" firms (z">2.6). The failure rate, calculated as the number of $\mathrm{z} "<1.1$ firms over the total number of sample firms is $2.09 \%$.

The results in Table 1 show that low z" firms have higher leverage ratios and lower ROA than high z" firms. The differences are statistically significant at the $1 \%$ level. This indicates that firms with smaller $z$ "-scores have significantly higher distress risk and leverage ratios and make significantly lower profits than firms within the 
higher z"-score group. The evidence on low z" firms is consistent with the characteristics associated with distressed firms. Therefore, low z" firms represent Chinese distressed firms well and high z" firms can represent non-distressed firms. The prior-year returns of low z" firms are significantly lower than those of their counterparts, showing that distressed firms underperform non-distressed firms in China's stock market. This result is consistent with the findings of Agarwal and Taffler (2008), Campbell et al. (2008), and Dichev (1998) on the US and UK stock markets.

Table 1. Summary statistics of firm characteristics

\begin{tabular}{|c|c|c|c|}
\hline & $\mathrm{z} "<1.1$ & $\mathrm{z} ">2.6$ & Diff \\
\hline Number of Firms & 527 & 24712 & \\
\hline Average z"-Score & 0.61 & 7.38 & $\begin{array}{c}-6.77 * * * \\
(-27.23)\end{array}$ \\
\hline Average Leverage & 0.74 & 0.43 & $\begin{array}{c}0.31 * * * \\
(18.59)\end{array}$ \\
\hline Average ROA & -0.06 & 0.04 & $\begin{array}{c}-0.10 * * * \\
(-25.94)\end{array}$ \\
\hline Average Prior-Year Stock Returns & 0.26 & 0.32 & $\begin{array}{c}-0.06^{* *} \\
(-2.37) \\
\end{array}$ \\
\hline
\end{tabular}

To examine the relationship between the size, $\mathrm{B} / \mathrm{M}$, and momentum factors and the distress risk, I use Carhart's (1997) four-factor model. The size is measured by the market capitalization (ME) on December 31 of each year. $\mathrm{B} / \mathrm{M}$ is the ratio of the book value of equity to the market value of equity on December 31 of each year. The momentum factor is constructed as the buy-and-hold returns in the prior 11 months (skipping the most recent month before the portfolio formation date). For example, the return momentum for the portfolio formed on December 31, 1998 is measured as the buy-and-hold returns from January 1, 1998 to November 30, 1998 (skipping December). The portfolios are rebalanced on January 1 of each year. Carhart's (1997) four-factor model is specified as

$$
R_{i, t}-R F_{t}=\alpha+b\left(R M_{t}-R F_{t}\right)+s S M B_{t}+h H M L_{t}+p U M D_{t}+\varepsilon_{i, t}
$$

where $\mathrm{R}_{i, t}$ is the monthly returns of value-weighted portfolio $i$, which consists of A-shares listed on the Shanghai and the Shenzhen Stock Exchange; $\mathrm{RF}_{t}$ is the risk-free rate for month $t ; \mathrm{RM}_{t}$ is the value-weighted average of the aggregate market; and $\mathrm{SMB}_{t}, \mathrm{HML}_{t}$, and $\mathrm{UMD}_{t}$ are the value-weighted returns on factor-mimicking portfolios for size, $\mathrm{B} / \mathrm{M}$, and momentum in stock returns.

I follow the same procedure as Fama and French (1993) to form SMB and HML. The sample A-shares are sorted by the year-end ME and B/M. Six portfolios are formed from two rankings on ME and three rankings on B/M. The median market capitalization is used as a breakpoint for ME and the $30^{\text {th }}$ and $70^{\text {th }}$ quantiles for B/M. SMB is the return difference between small ME and big ME, and HML is the excess return of the high $\mathrm{B} / \mathrm{M}$ over its low counterparts. The UMD factor is formed according to Carhart (1997). I sort the sample by the momentum in stock returns, which is the buy-and-hold returns in the prior 11-month. For example, the return momentum for the portfolio formed on December 31, 1998 is measured with the buy-and-hold returns from January 1, 1998 to November 30, 1998 (skipping December). UMD is calculated as the value-weighted average of the portfolios with the highest $30 \%$ momentum minus the value-weighted average of the portfolios with the lowest $30 \%$ momentum.

To explore the significance of the size, book-to-market, and momentum factors in capturing financial distress risk, I form three sets of portfolios, each of which consists of ten value-weighted portfolios. The first set contains size-sorted portfolios, the second set consists of B/M-sorted portfolios, and the last set is the collection of momentum-sorted portfolios. Specifically, I divide firms into two categories $-\mathrm{z}$ " $<1.1$ group and z" $>2.6$ group and then sort the firms in each category into quintile portfolios by size, B/M, and momentum in stock returns. Additionally, to capture the factor risks (size, book-to-market, and momentum), I construct zero-investment portfolios within each set of portfolios. Within the size-sorted portfolios, I form zero-investment size portfolios by buying small firms and selling big firms. For B/M-sorted portfolios, zero-investment B/M portfolios are created by buying high $\mathrm{B} / \mathrm{M}$ and selling low B/M quintiles. Lastly, I form zero-investment momentum portfolios by buying past winners and selling past losers within z" $<1.1$ and z" $>2.6$ group.

\section{Empirical Results}

The objective of this paper is to explore the significance of the size, book-to-market and momentum factors in 
capturing financial distress risk. Table 2 displays the summary statistics of the characteristics of the three sets of portfolios, with Panel A showing size portfolios, Panel B showing B/M portfolios, and Panel C showing momentum portfolios.

Table 2. Summary characteristics of size-, B/M-, and momentum-sorted portfolios

\begin{tabular}{|c|c|c|c|c|c|c|c|c|c|c|c|c|}
\hline \multicolumn{13}{|c|}{ Panel A: SIZE Portfolios } \\
\hline \multirow[b]{3}{*}{ Small } & \multirow{3}{*}{$\frac{x "<1.1}{237}$} & \multirow{2}{*}{\multicolumn{2}{|c|}{$\begin{array}{l}\text { No of Firms } \\
\text { z">2.6 Failure Rate }(\%)\end{array}$}} & \multicolumn{3}{|c|}{ Average ME $\left(\times 10^{9} \mathrm{RMB}\right)$} & \multicolumn{3}{|c|}{ Average B/M } & \multicolumn{3}{|c|}{ Average Momentum Returns } \\
\hline & & & & \multirow{2}{*}{$\frac{\mathrm{z} "<1.1}{1.13}$} & \multirow{2}{*}{$\frac{\mathrm{z} ">2.6}{1.28}$} & \multirow{2}{*}{$\begin{array}{c}\text { Diff } \\
-0.14 * * \\
(-2.02)\end{array}$} & \multirow{2}{*}{$\frac{\mathrm{z} "<1.1}{1.01}$} & \multirow{2}{*}{$\frac{\text { z">2.6 }}{4.41}$} & \multirow{2}{*}{$\begin{array}{c}\text { Diff } \\
-3.40 * * * \\
(-4.03)\end{array}$} & \multirow{2}{*}{$\frac{\mathrm{z} "<1.1}{0.34}$} & \multirow{2}{*}{$\frac{\text { z">2.6 }}{0.39}$} & \multirow{2}{*}{$\begin{array}{c}\text { Diff } \\
-0.05^{*} \\
(-1.85)\end{array}$} \\
\hline & & 4417 & 5.09 & & & & & & & & & \\
\hline 2 & 126 & 4731 & 2.59 & 1.86 & 2.32 & $\begin{array}{c}-0.46^{* * *} \\
(-3.36)\end{array}$ & 0.26 & 0.47 & $\begin{array}{c}-0.21 * * * \\
(-3.43)\end{array}$ & 0.34 & 0.35 & $\begin{array}{l}-0.01 \\
(-1.50)\end{array}$ \\
\hline 3 & 76 & 4990 & 1.50 & 3.08 & 3.36 & $\begin{array}{l}-0.28 \\
(-1.12)\end{array}$ & 0.37 & 0.45 & $\begin{array}{l}-0.08 \\
(-1.61)\end{array}$ & 0.29 & 0.32 & $\begin{array}{l}-0.03 \\
(-0.55)\end{array}$ \\
\hline 4 & 53 & 5188 & 1.01 & 4.78 & 5.41 & $\begin{array}{l}-0.63^{*} \\
(-1.71)\end{array}$ & 0.37 & 0.43 & $\begin{array}{l}-0.06 \\
(-1.29)\end{array}$ & 0.24 & 0.27 & $\begin{array}{l}-0.03 \\
(-0.03)\end{array}$ \\
\hline Big & 35 & 5386 & 0.65 & 17.24 & 22.79 & $\begin{array}{l}-5.55 \\
(-1.67)\end{array}$ & 0.59 & 0.42 & $\begin{array}{c}0.17 \\
(1.03)\end{array}$ & 0.18 & 0.21 & $\begin{array}{l}-0.04 \\
(-0.87)\end{array}$ \\
\hline Small-Big & & & & $\begin{array}{c}-16.11 * * * \\
(-5.10) \\
\end{array}$ & $\begin{array}{l}-21.52^{* * *} \\
(-18.69)\end{array}$ & $\begin{array}{c}5.41 * * * \\
(2.60) \\
\end{array}$ & $\begin{array}{l}0.42 * * \\
(2.22)\end{array}$ & $\begin{array}{l}3.99^{* * *} \\
(20.45)\end{array}$ & $\begin{array}{l}-3.56 * * * \\
(-13.05) \\
\end{array}$ & $\begin{array}{l}0.16^{* *} \\
(2.91) \\
\end{array}$ & $\begin{array}{r}0.18 * * * \\
(11.99) \\
\end{array}$ & $\begin{array}{l}-0.02 * * \\
(-1.96) \\
\end{array}$ \\
\hline \multicolumn{13}{|c|}{ Panel B: B/M Portfolios } \\
\hline & & No o & & Average & ME $(\times 10$ & 9 RMB) & & verage $B /$ & $/ \mathbf{M}$ & Average & Momentu & $\overline{\text { m Returns }}$ \\
\hline & $\underline{z "}<1.1$ & $z^{\prime \prime}>2.6$ & re Rate $(\%)$ & $\mathrm{z} "<1.1$ & z">2.6 & Diff & $\mathrm{z} "<1.1$ & z">2.6 & Diff & $\mathrm{z} "<1.1$ & z">2.6 & Diff \\
\hline Low & 270 & 4101 & 6.18 & 2.16 & 7.42 & $\begin{array}{c}-5.26 * * * \\
(-6.64)\end{array}$ & 0.14 & 0.16 & $\begin{array}{c}-0.02 * * * \\
(-3.90)\end{array}$ & 0.09 & 0.13 & $\begin{array}{c}-0.05 * * * \\
(-4.69)\end{array}$ \\
\hline 2 & 92 & 4804 & 1.88 & 3.29 & 6.07 & $\begin{array}{c}-2.77 * * * \\
(-2.77)\end{array}$ & 0.27 & 0.28 & $\begin{array}{l}-0.01 \\
(-1.17)\end{array}$ & 0.10 & 0.19 & $\begin{array}{l}-0.09 * \\
(-1.76)\end{array}$ \\
\hline 3 & 52 & 5067 & 1.02 & 3.32 & 6.46 & $\begin{array}{c}-3.14 * * * \\
(-3.64)\end{array}$ & 0.37 & 0.43 & $\begin{array}{c}-0.06 * * * \\
(-3.31)\end{array}$ & 0.11 & 0.26 & $\begin{array}{l}-0.16^{*} \\
(-1.77)\end{array}$ \\
\hline 4 & 39 & 5352 & 0.72 & 3.78 & 6.46 & $\begin{array}{l}-2.69 * * \\
(-2.03)\end{array}$ & 0.49 & 0.51 & $\begin{array}{l}-0.02 \\
(-0.52)\end{array}$ & 0.23 & 0.37 & $\begin{array}{l}-0.14 \\
(-1.16)\end{array}$ \\
\hline High & 74 & 5388 & 1.35 & 4.51 & 9.88 & $\begin{array}{c}-5.37 * * * \\
(-4.37)\end{array}$ & 3.16 & 4.08 & $\begin{array}{l}-0.91 * \\
(-1.92)\end{array}$ & 0.33 & 0.64 & $\begin{array}{l}-0.31 \\
(-0.38)\end{array}$ \\
\hline High-Low & & & & $\begin{array}{c}2.35 \\
(1.57) \\
\end{array}$ & $\begin{array}{c}2.46^{* * * *} \\
(2.64) \\
\end{array}$ & $\begin{array}{l}-0.11 * \\
(-1.65) \\
\end{array}$ & $\begin{array}{c}3.02 * * * \\
(6.75)\end{array}$ & $\begin{array}{l}3.92 * * * \\
(21.35)\end{array}$ & $\begin{array}{c}-0.90^{* *} \\
(-1.85)\end{array}$ & $\begin{array}{l}0.24 * * \\
(2.22)\end{array}$ & $\begin{array}{r}0.50 * * * \\
(27.58)\end{array}$ & $\begin{array}{c}-0.26 * * * \\
(-2.38) \\
\end{array}$ \\
\hline \multicolumn{13}{|c|}{ Panel C: Momentum Portfolios } \\
\hline & & No o & & \multicolumn{3}{|c|}{ Average ME (×109 RMB) } & \multicolumn{3}{|c|}{ Average $\mathbf{B} / \mathbf{M}$} & \multicolumn{3}{|c|}{ Average Momentum Returns } \\
\hline & z" $<1.1$ & z">2.6 & re Rate $(\%)$ & z" $<1.1$ & z">2.6 & Diff & z" $<1.1$ & $\mathrm{z} ">2.6$ & Diff & $\mathrm{z} "<1.1$ & z">2.6 & Diff \\
\hline Loser & 169 & 4691 & 3.48 & 3.14 & 6.64 & $\begin{array}{c}-3.51 * * * \\
(-6.13)\end{array}$ & 0.96 & 1.83 & $\begin{array}{c}-0.87 * * * \\
(-4.32)\end{array}$ & -0.35 & -0.16 & $\begin{array}{c}-0.19 * * * \\
(-7.51)\end{array}$ \\
\hline 2 & 87 & 4952 & 1.73 & 2.66 & 5.90 & $\begin{array}{c}-3.24 * * * \\
(-6.98)\end{array}$ & 0.91 & 1.22 & $\begin{array}{c}-0.30 \\
(-1.02)\end{array}$ & 0.04 & 0.11 & $\begin{array}{c}-0.07 \\
(-1.60)\end{array}$ \\
\hline 3 & 96 & 4942 & 1.91 & 2.33 & 6.59 & $\begin{array}{c}-4.27 * * * \\
(-6.14)\end{array}$ & 0.42 & 1.02 & $\begin{array}{c}-0.59 * * * \\
(-3.80)\end{array}$ & 0.20 & 0.21 & $\begin{array}{c}-0.02 \\
(-0.33)\end{array}$ \\
\hline 4 & 86 & 5056 & 1.67 & 3.19 & 7.17 & $\begin{array}{c}-3.98 * * * \\
(-6.42)\end{array}$ & 0.35 & 0.86 & $\begin{array}{c}-0.51 * * * \\
(-5.45)\end{array}$ & 0.39 & 0.63 & $\begin{array}{c}-0.23 * * * \\
(-3.69)\end{array}$ \\
\hline Winner & 89 & 5071 & 1.72 & 3.78 & 8.11 & $\begin{array}{c}-4.33 * * * \\
(-4.13)\end{array}$ & 0.33 & 0.85 & $\begin{array}{c}-0.52 * * * \\
(-5.26)\end{array}$ & 0.99 & 1.26 & $\begin{array}{l}-0.26 \\
(-1.43)\end{array}$ \\
\hline Winner-Loser & & & & $\begin{array}{c}0.64 \\
(0.55)\end{array}$ & $\begin{array}{l}1.47 * \\
(1.70)\end{array}$ & $\begin{array}{l}-0.82 * * \\
(-2.05)\end{array}$ & $\begin{array}{c}-0.63 * * * \\
(-3.53)\end{array}$ & $\begin{array}{c}-0.98 * * * \\
(-7.23)\end{array}$ & $\begin{array}{c}0.35 \\
(1.55)\end{array}$ & $\begin{array}{l}1.35 \text { *** } \\
(12.05)\end{array}$ & $\begin{array}{l}1.42 * * * \\
(22.08)\end{array}$ & $\begin{array}{l}-0.07 * * \\
(-2.60)\end{array}$ \\
\hline
\end{tabular}

Panel A provides some preliminary evidence that the size factor does not capture the distress risk in Chinese stocks. Regarding the size portfolios, the number of low z" firms decreases monotonically from 237 to 35 as the firm size increases. The failure rate within the small quintile is the highest, with a value of $5.09 \%$, while the failure rate within the big quintile is only $0.65 \%$. This indicates that small firms contains a large group of 
distressed firms. The size comparison of low z" and high z" firms indicates that low z" firms are smaller than high z" firms. However, the size risk within low z" firms is not rewarded by higher stock returns as the average momentum returns of low z" firms are lower than that of high z" firms within each size quintile. This is inconsistent with the studies by Chan and Chen (1991) and Chan et al. (1985) in that the size effect may be related to distress risk. The findings regarding "Small-Big" portfolios showing that the size differential between low z" and high z" firms is $5.41 \times 10^{9} \mathrm{RMB}(t$-statistic $=2.60)$ while the differences in momentum returns are -0.02 ( $t$-statistic $=-1.96)$ further confirm the result. Panel B summarizes the characteristics of the B/M quintiles as well as the zero-investment B/M portfolios. The number of low z" firms becomes less as firms move from low to high $\mathrm{B} / \mathrm{M}$ quintiles, as does the failure rate, except for the case of the highest $\mathrm{B} / \mathrm{M}$ quintile, in which there are 74 low z" firms and the failure rate is $1.35 \%$. The evidence that the momentum returns increase monotonically when low z" or high z" firms move from low to high B/M quintiles shows that book-to-market effects exist within low z" or high z" groups. However, little evidence shows that the book-to-market effects can be explained by the distress risk because low z" firms have lower momentum returns than high z" firms across all $\mathrm{B} / \mathrm{M}$ quintiles. The evidence from the zero-investment $\mathrm{B} / \mathrm{M}$ portfolios confirms the findings, as low $\mathrm{z}$ " firms has less momentum returns (0.24) than high z" firms $(0.50)$ and the differential in momentum returns $(-0.26)$ is significant at $1 \%$ level. Panel $\mathrm{C}$ reports the summary statistics of characteristics of momentum-sorted portfolios. The number of low z" firms and the failure rate declines as firms move from past losers to past winners. I find that, within each momentum return quintile, the low z" firms earn less momentum returns than high z" firms. This result exists in the size- and B/M-sorted portfolios. Combing results of momentum returns in Panels A, B, and $\mathrm{C}$, I find that distressed firms consistently underperform non-distressed firms, regardless of their size or book-to-market ratio. The result is consistent with the market underreaction hypothesis.

\subsection{Size and Distress Risk}

To examine whether the size effect captures the distress risk in China's stock market, I regress the excess returns of the size portfolios on the market excess returns and SMB, HML, and UMD factors for both low z" and high z" firms. The regression results for low z" firms and high z" firms display in Panels A and B of Table 3, respectively. Within each size quintile, I form a zero-investment portfolio that longs the low z" firms and shorts the high z" firms. The results are in Panel C. In each panel, I also create a zero-investment portfolio, labeled "Small-Big", by buying small and selling big quintiles to evaluate the size effects among low z" and high z" groups.

Table 3. Four-factor model regressions based on size portfolios

\begin{tabular}{|c|c|c|c|c|c|c|}
\hline \multicolumn{7}{|c|}{ Panel A: z" $>1.1$ Firms } \\
\hline \multirow{3}{*}{$\alpha$} & Small & 2 & 3 & 4 & Big & Small-Big \\
\hline & -0.008 & $-0.008 *$ & -0.010 & $-0.014 * * *$ & -0.005 & -0.003 \\
\hline & $(-0.66)$ & $(-1.73)$ & $(-1.63)$ & $(-2.93)$ & $(-1.04)$ & $(-0.19)$ \\
\hline \multirow[t]{2}{*}{ RM-RF } & $0.95^{* * *}$ & $1.05 * * *$ & $0.91 * * *$ & $1.09^{* * * *}$ & $1.02 * * *$ & -0.07 \\
\hline & $(7.33)$ & $(14.42)$ & $(12.29)$ & $(14.96)$ & $(9.49)$ & $(-0.42)$ \\
\hline \multirow[t]{2}{*}{ SMB } & $1.08^{* * * *}$ & $1.06 * * *$ & $0.88^{* * *}$ & $0.65^{* * * *}$ & $0.33^{* * * *}$ & $0.76 * * *$ \\
\hline & $(5.31)$ & $(8.54)$ & $(6.04)$ & $(4.81)$ & $(2.80)$ & $(3.22)$ \\
\hline \multirow{2}{*}{ HML } & -0.26 & -0.15 & 0.09 & 0.08 & 0.18 & $-0.44 *$ \\
\hline & $(-1.20)$ & $(-0.86)$ & $(0.39)$ & $(0.59)$ & $(1.12)$ & $(-1.63)$ \\
\hline \multirow[t]{2}{*}{ UMD } & -0.48 & -0.08 & $-0.39 * * *$ & $-0.32 * * *$ & -0.15 & -0.33 \\
\hline & $(-1.02)$ & $(-0.68)$ & $(-2.71)$ & $(-2.65)$ & $(-1.07)$ & $(-0.68)$ \\
\hline \multicolumn{7}{|c|}{ Panel B: z">2.6 Firms } \\
\hline \multirow{3}{*}{$\alpha$} & Small & 2 & 3 & 4 & Big & Small-Big \\
\hline & 0.003 & -0.001 & $-0.003 *$ & $-0.004^{* *}$ & -0.001 & $0.004 *$ \\
\hline & (1.62) & $(-0.76)$ & $(-1.69)$ & $(-2.03)$ & $(-0.80)$ & (1.79) \\
\hline \multirow[t]{2}{*}{ RM-RF } & $1.03 * * *$ & $1.01 * * *$ & $1.03^{* * *}$ & $1.03^{* * *}$ & $0.99 * * *$ & 0.04 \\
\hline & (30.11) & $(50.30)$ & $(42.35)$ & (39.63) & (49.85) & $(0.97)$ \\
\hline \multirow[t]{2}{*}{ SMB } & $1.25^{* * *}$ & $1.09 * * *$ & $0.88^{* * *}$ & $0.64^{* * * *}$ & $0.14^{* * *}$ & $1.11^{* * *}$ \\
\hline & (19.49) & (17.28) & (12.64) & $(9.16)$ & $(3.02)$ & (14.07) \\
\hline \multirow[t]{2}{*}{ HML } & 0.01 & 0.02 & 0.01 & -0.02 & $0.10^{* *}$ & -0.08 \\
\hline & $(0.22)$ & $(0.23)$ & $(0.19)$ & $(-0.33)$ & (2.64) & $(-1.22)$ \\
\hline \multirow[t]{2}{*}{ UMD } & $0.11^{*}$ & $0.10^{*}$ & $0.11^{*}$ & $0.14 * *$ & $0.07 * *$ & 0.03 \\
\hline & (1.74) & (1.74) & (1.82) & $(2.24)$ & $(2.48)$ & $(0.51)$ \\
\hline
\end{tabular}




\begin{tabular}{|c|c|c|c|c|c|c|}
\hline \multicolumn{7}{|c|}{ Panel C: z"<1.1 Firms Minus z">2.6 Firms } \\
\hline \multirow{3}{*}{$\alpha$} & Small & 2 & 3 & 4 & Big & Small-Big \\
\hline & $-0.011 * * *$ & $-0.007 * * *$ & $-0.007 * * *$ & $-0.010^{* *}$ & -0.005 & -0.006 \\
\hline & $(-3.00)$ & $(-3.43)$ & $(-4.12)$ & $(-1.96)$ & $(-0.85)$ & $(-0.47)$ \\
\hline \multirow[t]{2}{*}{ RM-RF } & -0.08 & 0.03 & -0.12 & 0.06 & 0.03 & -0.11 \\
\hline & $(-0.56)$ & $(0.43)$ & $(-1.50)$ & $(0.73)$ & $(0.31)$ & $(-0.63)$ \\
\hline \multirow[t]{2}{*}{ SMB } & -0.17 & -0.03 & $0.00^{* *}$ & $0.01 * *$ & $0.19^{* *}$ & $-0.36 * * *$ \\
\hline & $(-0.80)$ & $(-0.24)$ & $(2.01)$ & $(2.03)$ & $(2.49)$ & $(-2.44)$ \\
\hline \multirow[t]{2}{*}{ HML } & -0.27 & -0.17 & 0.08 & 0.10 & 0.08 & -0.36 \\
\hline & $(-1.22)$ & $(-0.89)$ & $(0.32)$ & $(0.68)$ & $(0.50)$ & $(-1.28)$ \\
\hline \multirow[t]{2}{*}{ UMD } & -0.58 & -0.17 & $-0.50 * * *$ & $-0.46^{* * *}$ & $-0.22 *$ & -0.36 \\
\hline & $(-1.24)$ & $(-1.38)$ & $(-3.21)$ & $(-3.38)$ & $(-1.56)$ & $(-0.74)$ \\
\hline
\end{tabular}

The factor loadings on the market and the size in Panels A and B are highly significant. The size effect exists in both low z" and high z" firms, as the factor loadings on SMB of both groups decline monotonically from small to big quintiles and are strongly significant. The SMB coefficients in the "Small-Big" portfolio are 0.76 for low z" firms and 1.11 for high z" firms, both of which are statistically significant at $1 \%$ level. These findings indicate that the size effect plays an important role in explaining the stock return anomalies in China's market. However, little evidence supports the assertion that the size effect is driven by distressed firms, as in the "Small-Big" portfolios, low z" firms earn lower risk-adjusted returns (-0.003 with $t$-statistics of -0.19$)$ than high z" firms (0.004 with $t$-statistics of 1.79). Panel C exhibits a significantly negative $\alpha$ within the smaller quintiles, indicating that, have controlled for size, distressed firms earn significantly lower risk-adjusted returns than non-distressed firms. In general, the size effect has explanatory power in the return anomalies in China's stock market, but cannot be explained by distress risk.

\subsection{Book-to-Market and Distress Risk}

This section examines significance of book-to-market effect in capturing distress risk in China's market. Table 4 presents the four-factor model regressions based on the $\mathrm{B} / \mathrm{M}$ portfolios. The "High-Low" portfolio is a zero-investment portfolio created by buying high $\mathrm{B} / \mathrm{M}$ quintile and selling low $\mathrm{B} / \mathrm{M}$ quintile. In Panel $\mathrm{A}$, the factor loadings on HML are insignificant for all except the fourth $\mathrm{B} / \mathrm{M}$ quintile $(0.92$ with $t$-statistic $=3.84)$. The "High-Low" portfolio exhibits the book-to-market effect with the significant HML coefficient of 0.97 ( $t$-statistic = 2.20). In Panel B, high $\mathrm{z}$ " firms show a strong book-to-market effect, as the factor loadings of HML rise monotonically from low to high B/M quintiles and are strongly significant as well. Additionally, the HML coefficient in "High-Low" portfolio is 0.72 and highly significant $(t$-statistic $=10.97)$. The findings support the ideas that a positive premium is related to the book-to-market factor in China's stock market and that the premium is mainly driven by non-distressed firms. Furthermore, I also can find the book-to-market effect in Panel C, in which the "High-Low" portfolio has significant $\alpha$ value $(0.006$ with $t$-statistic $=2.65)$. This indicates that the book-to-market factor cannot proxy for distress risk. This finding is consistent with Agarwal and Taffler (2008), Campbell et al. (2008), and Dichev (1998).

Table 4. Four-factor model regressions based on B/M portfolios

\begin{tabular}{|c|c|c|c|c|c|c|}
\hline \multicolumn{7}{|c|}{ Panel A: $\mathrm{z} "<1.1$ Firms } \\
\hline \multirow{3}{*}{$\alpha$} & Low & 2 & 3 & 4 & High & High-Low \\
\hline & $-0.012 * * *$ & -0.015 & -0.004 & -0.011 & -0.008 & 0.004 \\
\hline & $(-3.14)$ & $(-0.84)$ & $(-0.67)$ & $(-1.64)$ & $(-0.92)$ & $(0.39)$ \\
\hline \multirow[t]{2}{*}{ RM-RF } & $0.96^{* * *}$ & $0.93 * * *$ & $0.91 * * *$ & $0.95 * * *$ & $1.18^{* * *}$ & 0.22 \\
\hline & (15.24) & $(4.27)$ & $(10.56)$ & (11.10) & $(5.54)$ & $(0.99)$ \\
\hline \multirow[t]{2}{*}{ SMB } & $0.40^{* * *}$ & 0.53 & $0.89 * * *$ & $1.03 * * *$ & $1.04 * *$ & 0.64 \\
\hline & $(10.51)$ & $(1.25)$ & $(4.37)$ & $(5.90)$ & $(2.04)$ & $(1.25)$ \\
\hline \multirow[t]{2}{*}{ HML } & 0.13 & 0.23 & 0.30 & $0.92 * * *$ & 1.10 & $0.97 * *$ \\
\hline & $(1.26)$ & $(0.46)$ & $(1.05)$ & $(3.84)$ & $(1.51)$ & $(2.20)$ \\
\hline \multirow[t]{2}{*}{ UMD } & $-0.01 *$ & -1.51 & -0.18 & -0.12 & -0.19 & -0.18 \\
\hline & $(-0.09)$ & $(-1.21)$ & $(-1.02)$ & $(-0.78)$ & $(-0.29)$ & $(-0.28)$ \\
\hline
\end{tabular}




\begin{tabular}{|c|c|c|c|c|c|c|}
\hline \multicolumn{7}{|c|}{ Panel B: z">2.6 Firms } \\
\hline \multirow{3}{*}{$\alpha$} & Low & 2 & 3 & 4 & High & High-Low \\
\hline & -0.001 & -0.002 & -0.001 & -0.002 & $-0.003^{*}$ & -0.002 \\
\hline & $(-0.30)$ & $(-0.73)$ & $(-0.62)$ & $(-1.21)$ & $(-1.83)$ & $(-0.89)$ \\
\hline \multirow[t]{2}{*}{$\mathrm{RM}-\mathrm{RF}$} & $1.03^{* * *}$ & $1.01 * * *$ & $1.05^{* * *}$ & $1.02 * * *$ & $0.96^{* * *}$ & -0.07 \\
\hline & $(31.68)$ & $(29.70)$ & $(32.59)$ & (47.39) & $(41.26)$ & $(-1.46)$ \\
\hline \multirow[t]{2}{*}{ SMB } & $0.14 * *$ & $0.30 * * *$ & $0.31^{* * *}$ & $0.37 * * *$ & $0.24 * * *$ & 0.10 \\
\hline & $(2.56)$ & $(4.02)$ & $(4.34)$ & $(5.74)$ & $(3.87)$ & (1.17) \\
\hline \multirow[t]{2}{*}{ HML } & $0.09 * * *$ & $0.25^{* * *}$ & $0.29 * * *$ & $0.62 * * *$ & $0.81 * * *$ & $0.72 * * *$ \\
\hline & $(10.93)$ & $(5.15)$ & $(2.55)$ & $(3.64)$ & $(12.47)$ & $(10.97)$ \\
\hline \multirow{2}{*}{ UMD } & $0.22 * * *$ & 0.08 & $0.12 * *$ & 0.07 & 0.01 & $-0.20 * * *$ \\
\hline & $(4.89)$ & $(1.25)$ & $(2.18)$ & $(1.23)$ & $(0.34)$ & $(-3.28)$ \\
\hline \multicolumn{7}{|c|}{ Panel C: z" $<1.1$ Firms Minus z">2.6 Firms } \\
\hline \multirow{3}{*}{$\alpha$} & Low & 2 & 3 & 4 & High & High-Low \\
\hline & $-0.011 * * *$ & -0.013 & -0.003 & -0.009 & -0.005 & $0.006^{* *}$ \\
\hline & $(-2.64)$ & $(-0.75)$ & $(-0.46)$ & $(-1.33)$ & $(-0.59)$ & $(2.65)$ \\
\hline \multirow[t]{2}{*}{ RM-RF } & -0.07 & -0.08 & -0.15 & -0.06 & 0.22 & 0.29 \\
\hline & $(-1.05)$ & $(-0.37)$ & $(-1.59)$ & $(-0.72)$ & $(1.01)$ & $(1.29)$ \\
\hline \multirow[t]{2}{*}{ SMB } & $0.26^{* * *}$ & 0.23 & $0.58^{* * *}$ & $0.66^{* * *}$ & $0.81^{*}$ & $0.55^{* *}$ \\
\hline & $(3.85)$ & $(0.53)$ & $(2.67)$ & $(3.55)$ & $(1.56)$ & $(2.05)$ \\
\hline \multirow[t]{2}{*}{ HML } & 0.04 & -0.02 & 0.01 & $0.30^{* * *}$ & 0.29 & $0.26^{* *}$ \\
\hline & $(0.36)$ & $(-0.05)$ & $(0.04)$ & (3.02) & $(0.40)$ & $(2.40)$ \\
\hline \multirow[t]{2}{*}{ UMD } & $-0.23^{* *}$ & -1.59 & -0.30 & -0.19 & -0.21 & 0.02 \\
\hline & $(2.38)$ & $(-1.27)$ & $(-1.59)$ & $(-1.15)$ & $(-0.31)$ & $(0.03)$ \\
\hline
\end{tabular}

\subsection{Momentum and Distress Risk}

In this section I attempt to investigate whether the momentum effect proxies for distress risk. Table 5 reports the regression results for the return momentum quintiles. Panels A and B show that for both low z" and high z" groups, the loadings on the UMD factor exhibit an upward trend as firms move from past losers to past winners. In addition I find that the $\alpha$ values for low z" firms are negative, while the $\alpha$ values for high $\mathrm{z}$ " firms are all positive and highly significant. This suggests that the past losers are likely to lose again in the future and the past winners are more likely to succeed in the future. Our findings confirm the study by Agarwal and Taffler (2008), which concludes that the return momentum is caused by the medium-term continuation of prior returns. Panel C displays a negative $\alpha$ across all the momentum quintiles. This implies that the distressed firms always underperform the non-distressed firms. In addition, insignificant UMD loadings across all the momentum quintiles indicate that when controlling for distress risk, the momentum effect disappears. I construct the "Winner-Loser" portfolios by buying past winner and selling past losers to evaluate the momentum effects among different portfolios. In all the low z" or high z" groups, the $\alpha$ values and the UMD loadings in the "Winner-Loser" portfolios are both positive and significant, which implies strong momentum effects among distressed and non-distressed firms. In Panel $\mathrm{C}$ the insignificant $\alpha$ value and the UMD loading in the "Winner-Loser" portfolios further confirm that distress risk subsumes the momentum effect. Altogether our results indicate that the momentum effect proxies for distress risk.

Table 5. Four-factor model regressions based on momentum portfolios

\begin{tabular}{|c|c|c|c|c|c|c|}
\hline \multicolumn{7}{|c|}{ Panel A: $\mathrm{z} "<1.1$ Firms } \\
\hline \multirow{3}{*}{$\alpha$} & Loser & 2 & 3 & 4 & Winner & Winner-Loser \\
\hline & -0.073 & -0.000 & -0.014 & -0.003 & -0.004 & $0.069 * *$ \\
\hline & $(1.13)$ & $(-0.05)$ & $(0.15)$ & $(-0.49)$ & $(-0.19)$ & $(2.14)$ \\
\hline \multirow[t]{2}{*}{ RM-RF } & 0.22 & $1.02 * * *$ & $0.98 * * *$ & $0.94 * * *$ & $1.08^{* * *}$ & 0.86 \\
\hline & $(0.28)$ & (11.98) & $(11.42)$ & $(11.52)$ & $(9.90)$ & $(1.10)$ \\
\hline \multirow[t]{2}{*}{ SMB } & 0.99 & $0.92 * * *$ & $0.76^{* * *}$ & $0.73^{* * *}$ & $0.57 * * *$ & -0.43 \\
\hline & $(0.38)$ & $(5.33)$ & $(4.10)$ & $(5.68)$ & $(5.71)$ & $(-0.16)$ \\
\hline \multirow[t]{2}{*}{ HML } & -1.67 & 0.12 & -0.04 & $0.44 * *$ & -0.17 & 1.51 \\
\hline & $(-0.87)$ & $(0.72)$ & $(-0.16)$ & (1.98) & $(-0.68)$ & $(0.78)$ \\
\hline \multirow[t]{2}{*}{ UMD } & -0.57 & $-0.43 * * *$ & -0.20 & 0.01 & $0.19 * *$ & $0.77 * *$ \\
\hline & $(-1.18)$ & $(-3.72)$ & $(-1.32)$ & $(0.01)$ & (2.64) & (2.48) \\
\hline
\end{tabular}




\begin{tabular}{|c|c|c|c|c|c|c|}
\hline \multicolumn{7}{|c|}{ Panel B: z">2.6 Firms } \\
\hline \multirow{3}{*}{$\alpha$} & Loser & 2 & 3 & 4 & Winner & Winner-Loser \\
\hline & $0.005 * * *$ & $0.006^{* * * *}$ & $0.007 * * *$ & $0.008 * * *$ & $0.012 * * *$ & $0.007 * *$ \\
\hline & $(2.64)$ & $(3.11)$ & $(3.28)$ & $(4.26)$ & $(5.90)$ & $(2.35)$ \\
\hline \multirow[t]{2}{*}{ RM-RF } & $1.05^{* * *}$ & $1.04 * * *$ & $1.04 * * *$ & $1.00^{* * *}$ & $1.04 * * *$ & -0.01 \\
\hline & $(44.78)$ & $(43.76)$ & $(30.27)$ & $(37.93)$ & $(37.10)$ & $(-0.17)$ \\
\hline \multirow[t]{2}{*}{ SMB } & $0.29 * * *$ & $0.31 * * *$ & $0.29 * * *$ & $0.27 * * *$ & $0.23 * * *$ & -0.06 \\
\hline & $(4.47)$ & $(4.17)$ & $(3.41)$ & $(3.67)$ & $(3.68)$ & $(-0.62)$ \\
\hline \multirow[t]{2}{*}{ HML } & -0.02 & 0.13 & -0.01 & -0.00 & $-0.16^{* *}$ & -0.15 \\
\hline & $(-0.24)$ & $(1.61)$ & $(-0.10)$ & $(-0.01)$ & $(-2.47)$ & $(-1.58)$ \\
\hline \multirow[t]{2}{*}{ UMD } & $-0.49 * * *$ & $-0.25 * * *$ & -0.06 & $0.18 * * *$ & $0.61 * * *$ & $1.10^{* * *}$ \\
\hline & $(-7.98)$ & $(-3.97)$ & $(-1.10)$ & $(3.49)$ & $(7.52)$ & $(10.82)$ \\
\hline \multicolumn{7}{|c|}{ Panel C: z" $<1.1$ Firms Minus z" $>2.6$ Firms } \\
\hline \multirow{3}{*}{$\alpha$} & Loser & 2 & 3 & 4 & Winner & Winner-Loser \\
\hline & -0.078 & -0.007 & -0.021 & -0.011 & $-0.016^{*}$ & 0.062 \\
\hline & $(1.05)$ & $(-1.35)$ & $(0.97)$ & $(-1.57)$ & $(-1.71)$ & $(1.24)$ \\
\hline \multirow[t]{2}{*}{ RM-RF } & -0.83 & -0.03 & -0.07 & -0.06 & 0.04 & 0.87 \\
\hline & $(-1.07)$ & $(-0.29)$ & $(-0.73)$ & $(-0.71)$ & $(0.32)$ & $(1.10)$ \\
\hline \multirow[t]{2}{*}{ SMB } & 0.71 & $0.61 * * *$ & $0.46 * *$ & $0.47 * * *$ & $0.34 * * *$ & -0.37 \\
\hline & $(0.27)$ & $(3.26)$ & $(2.28)$ & $(3.17)$ & $(2.84)$ & $(-0.14)$ \\
\hline \multirow[t]{2}{*}{ HML } & -1.66 & -0.00 & -0.04 & $0.44^{*}$ & -0.00 & 1.65 \\
\hline & $(-0.86)$ & $(-0.04)$ & $(-0.13)$ & $(1.80)$ & $(-0.01)$ & $(0.85)$ \\
\hline \multirow[t]{2}{*}{ UMD } & -0.08 & -0.17 & -0.13 & -0.18 & -0.41 & -0.33 \\
\hline & $(-0.17)$ & $(-1.33)$ & $(-0.85)$ & $(-0.87)$ & $(-1.13)$ & $(-0.62)$ \\
\hline
\end{tabular}

\section{Conclusions}

I address the primary question of whether size, book-to-market, or momentum factors proxy for distress risk to explain the cross-sectional variation in China's stock returns. The Carhart's (1997) four-factor model shows that the size and book-to-market effects have the explanatory power in the return anomalies in China's stock market. However, the size and book-to-market effects still exist when controlling for distress risk. This demonstrates that the size or book-to-market factors cannot explain financial distress risk. This finding is inconsistent with the distress factor hypothesis of Chan and Chen (1991) and Fama and French (1992). In contrast, I find that the momentum factor proxies for distress risk in our sample period, consistent with the market underreaction hypothesis of Agarwal and Taffler (2008). Moreover, the explanatory power of the momentum effect is subsumed when the distress factor is present in the model.

\section{References}

Agarwal, V., \& Taffler, R. (2008). Does financial distress risk drive the momentum anomaly? Financial Management, 37, 461-484. https://dx.doi.org/10.1111/j.1755-053X.2008.00021.x

Altman, E. I. (1968). Financial ratios, discriminant analysis and the prediction of corporate bankruptcy. Journal of Finance, 23, 589-609. https://dx.doi.org/10.1111/j.1540-6261.1968.tb00843.x

Altman, E. I. (1983). Corporate financial distress: A complete guide to predicting, avoiding, and dealing with bankruptcy. New York: Wiley Interscience, John Wiley and Sons.

Altman, E. I., Iwanicz-Drozdowska, M., Laitinen, E., \& Suvas, A. (2016). Financial distress prediction in an international context: A review and empirical analysis of Altman's Z-score model. Journal of International Financial Management \& Accounting. http://dx.doi.org/10.1111/jifm.12053

Campbell, J., Hilscher, J., \& Szilagyi, J. (2008). In search of distress risk. Journal of Finance, 63, 2899-2939. https://dx.doi.org/10.1111/j.1540-6261.2008.01416.x

Carhart, M. (1997). On the persistence of mutual fund performance. Journal of Finance, 52, 57-82. https://dx.doi.org/10.1111/j.1540-6261.1997.tb03808.x

Chan, K. C., \& Chen, N. F. (1991). Structural and return characteristics of small and large firms. Journal of Finance, 46, 1467-1484. https://dx.doi.org/10.1111/j.1540-6261.1991.tb04626.x

Chan, K. C., Chen, N. F., \& Hsieh, D. (1985). An exploratory investigation of the firm size effect. Journal of 
Financial Economics, 14, 451-471. https://dx.doi.org/10.1016/0304-405X(85)90008-X

Dichev, I. D. (1998). Is the risk of bankruptcy a systematic risk? Journal of Finance, 53, 1131-1147. https://dx.doi.org/10.1111/0022-1082.00046

Fama, E. F., \& French, K. R. (1992). The cross-section of expected stock returns. Journal of Finance, 47, 427-465. https://dx.doi.org/10.1111/j.1540-6261.1992.tb04398.x

Fama, E. F., \& French, K. R. (1993). Common risk factors in the returns on stocks and bonds. Journal of Financial Economics, 33, 3-56. https://dx.doi.org/10.1016/0304-405X(93)90023-5

Fama, E. F., \& French, K. R. (1995). Size and book-to-market factors in earnings and returns. Journal of Finance, 50, 131-155. https://dx.doi.org/10.1111/j.1540-6261.1995.tb05169.x

Fama, E. F., \& French, K. R. (1996). Multifactor explanations of asset pricing anomalies. Journal of Finance, 51, 55-84. https://dx.doi.org/10.1111/j.1540-6261.1996.tb05202.x

Ferguson, M. F., \& Shockley, R. L. (2003). Equilibrium "anomalies." Journal of Finance, 58, 2549-2580. https://dx.doi.org/10.1046/j.1540-6261.2003.00615.x

Frazzini, A. (2006). The disposition effect and underreaction to news. Journal of Finance, 61, 2017-2046. https://dx.doi.org/10.1111/j.1540-6261.2006.00896.x

Griffin, J., \& Lemmon, L. (2002). Book-to-market equity, distress risk, and stock returns. Journal of Finance, 57, 2317-2336. https://dx.doi.org/10.1111/1540-6261.00497

Grinblatt, M., \& Han, B. (2005). Prospect theory, mental accounting, and momentum. Journal of Financial Economics, 78, 311-339. https://dx.doi.org/10.1016/j.jfineco.2004.10.006

Jegadeesh, N., \& Titman, S. (1993). Returns to buying winners and selling losers: Implications for stock market efficiency. Journal of Finance, 48, 65-91. https://dx.doi.org/10.1111/j.1540-6261.1993.tb04702.x

Vassalou, M., \& Xing, Y. (2004). Default risk in equity returns. Journal of Finance, 59, 831-868. https://dx.doi.org/10.1111/j.1540-6261.2004.00650.x

\section{Notes}

Note 1. The Chinese stock market has been classified into three share classes: A-shares, B-shares, and $\mathrm{H}$-shares. A-shares denominated in RMB are only available to domestic investors, while B-shares are only open to foreign investors and are denominated in foreign currencies (US dollars on the Shanghai Stock Exchange and Hong Kong dollars on the Shenzhen Stock Exchange). Companies issuing H-shares have business on Mainland China but are listed on the Hong Kong Stock Exchange. H-shares are denominated in Hong Kong dollars and are mainly available to non-Chinese investors.

\section{Copyrights}

Copyright for this article is retained by the author(s), with first publication rights granted to the journal.

This is an open-access article distributed under the terms and conditions of the Creative Commons Attribution license (http://creativecommons.org/licenses/by/4.0/). 